\title{
A cross-sectional study: Collaborative learning approach enhances learning attitudes of undergraduate nursing students
}

\author{
Wong MF Florence \\ School of Nursing \\ Tung Wah College \\ Hong Kong \\ florencewong@twc.edu.hk
}

\begin{abstract}
Collaborative learning approach is an effective teaching method to receive optimal achievement in knowledge and skills. Since nursing is a profession that emphasizes multidisciplinary collaboration, collaborative learning approach has been commonly adopted in current nursing education to maximize students' learning and develop their collaborative attributes. It is important that learning attitudes shall be positive to reach benefits of collaborative learning. This study was to examine how learning attitudes of nursing undergraduate students in respond to collaborative learning approach. The results may help nursing school administrators design more appropriate learning activities and give educators insights to implement collaborative learning approach more effectively.
\end{abstract}

Keywords- collaborative learning; learning attitudes; nursing; undergraduate students

\section{INTRODUCTION}

Collaborative learning approach is a well-established and favorable teaching method for student learning as a pedagogical method to achieve intended learning outcomes (Gaudet et al., 2010; Hillyard et al., 2012; Ismail et al., 2011). This approach acts as an incentive for learning that enables students to work in a team on an assignment towards a common goal with instruction provided (Mabrouk, 2007). Collaborative learning embraces overarching purposes to maximize students' learning ability in knowledge enhancement, skill development, and social interaction (Chiriac, 2014; Copp, 2002; Hillyard et al., 2012; Laal et al., 2012). It also enables students to be active and responsible for their own role and learning and emphasizes on interaction, collaboration with individual accountability, and utilization of individual talents and group competences (Chiriac, 2014; Noohi, Abaszadeh, Maddah, 2013). As a result, students not only improve their individual learning skills and achieve more overall but also develop a higher level of a range of skills, including critical thinking, problem-solving, leadership and management, social interaction, and communication (Srinivas, 2015; van Offenbeek, 2001)

Collaborative learning approach has been increased in professional education, such as medical and dental trainings (Kanthan and Mills, 2007; Mueller-Joseph and NappoDattoma, 2013). Since nursing is the profession expected to work with various multidisciplinary healthcare teams, collaborative learning approach has been adopted in current nursing education to maximize students' learning and develop their collaborative attributes (Austria et al., 2013; Kanthan \& Mills, 2007; Mueller-Joseph \& Nappo-Dattoma, 2013). It is an important fact that collaborative learning approach needs engagement of each team member and commitment of his or her accountability for completion of the group project (Mabrouk, 2007; D'Souza et al., 2013). A recent study (D'Souza et al., 2013) reported that collaborative learning approach benefits nursing students' learning through engagement in clinical environment. Students were able to learning through mutual interaction, diversity experiences, shared learning opportunities, and active learning in collaborative learning. In the study of Chiriac (2014), nursing students were facilitated in both knowledge and collaborative ability through collaborative learning. Noohi (2013) supported that collaborative learning enhances academic engagement, facilitates interaction, and foster knowledge and skill development. While students indeed benefit from collaborative learning and more nursing programmes are adopting collaborative approaches, learning attitudes of individual team member may play a key role in motivation and achievement of learning (Hillyard et al., 2012). However, little is known about how nursing students actually respond to this learning approach. Therefore, the purpose of this study was to examine learning attitudes of undergraduate nursing students in collaborative learning and to identify variables influencing students' learning attitudes. The results may help nursing school administrators design more appropriate learning activities and give educators insights to implement collaborative learning approach more effectively.

\section{METHODS}

\section{A. Design and sampling}

A cross-sectional questionnaire survey was conducted in 2015. Sample size was estimated based on the priori power analysis using G-Power 3.1 was performed with an alpha level of 0.05 , power set at 0.85 and the effect size of 0.15 . A convenience sample of 327 participants who were undergraduate nursing students in Hong Kong were recruited at

DOI: 10.5176/2345-7198_5.1.27

ISSN 2345-7198

CThe Author(s) 2018. This article is published with open access by the GSTF 
a self-financial educational institution. Data were collected between January and August 2015.

\section{B. Data collection}

An ethical approval was obtained from the institutional Research Review Board of the educational institution before the study was commenced. After the eligible participants signed an informed consent, they were requested to fill in one set of questionnaires, including the demographic data form and the self-reported Student Attitudes toward Group Environment (SAGE) survey. It took about 20 minutes to complete the questionnaire.

The demographic characteristics included age, gender, study programme, year of study, and number of courses working in a group. The SAGE survey was specifically developed by Kouros and Abrami (2006) to assess students' learning attitudes toward group learning. The SAGE was a well-validated questionnaire that includes 53 attitude items using a five-point Likert scale ranging from "strongly agree" to "strongly disagree". There are four learning attitudinal domains retrieved from 43 items of the SAGE, namely quality of product and process, peer support, student interdependence, and frustrations with group members. The overall Cronbach's alpha was 0.77 , which indicated a high level of internal consistency for the SAGE in this study.

\section{ETHICAL CONSIDERATIONS}

The study was approved by the School Research Committee of the educational institution. All participants were assured that they could withdraw from the study without consequences at any time. All information was anonymous to protect personal confidentiality and only used for research purpose.

\section{DATA ANALYSIS}

Data were analyzed using the IBM SPSS v20.0 (SPSS Inc., Chicago, IL, USA). Descriptive statistics were used to summarize and analyze the students' demographics and the attitudinal domains of the SAGE. Pearson's coefficient was used to examine the relationships between variables. The level of significance was set at 0.05 for all statistical tests.

\section{RESULTS}

A total of 327 undergraduate nursing students completed the questionnaire.

\section{A. Demographic charcteristics}

There were 247 female students $(75.5 \%)$. The mean age was $20.4 \pm 1.83$ years old. The age range was from 18 to 31 years old. Of 327 students, $185(56.6 \%)$ were from the normal programme and $142(43.4 \%)$ were senior students who had entered the programme after completing the relevant associate degree. About $26.0 \%$ to $29.1 \%$ of students were involved in four to five group projects in one semester. Table I shows the details of demographic characteristics of the undergraduate nursing students.
TABLE I. DEMOGRAPHIC CHARACTERISTICS

\begin{tabular}{|l|c|c|}
\hline Variables & Number & Percentage \\
\hline Female & 247 & 75.5 \\
\hline Age & & \\
\hline $18-20$ & 202 & 61.8 \\
\hline $21-25$ & 120 & 36.7 \\
\hline $26-30$ & 4 & 1.2 \\
\hline$>30$ & 1 & 0.3 \\
\hline Study programmes & & 56.6 \\
\hline Normal year & 185 & 43.4 \\
\hline Senior year & 142 & 44.0 \\
\hline Year of study & & 42.8 \\
\hline 1 & 144 & 13.2 \\
\hline 2 & 140 & \\
\hline$\geq 3$ & 43 & 3.1 \\
\hline $\begin{array}{l}\text { Number of courses with group } \\
\text { work }\end{array}$ & & 8.6 \\
\hline 1 & 10 & 16.8 \\
\hline 2 & 28 & 26 \\
\hline 3 & 55 & 29.1 \\
\hline 4 & 85 & 16.5 \\
\hline 5 & 95 & \\
\hline$>5$ & 54 & \\
\hline
\end{tabular}

\section{B. Learning attitudes}

Based on the SAGE, the majority of students ( 84\%) agreed with choosing their friends as their team members and agreed that it was important to get the work done on time in a group $(\sim 81 \%)$. They also agreed that they were able to share their ideas while working in a group ( $76 \%)$. On the other hand, most of the students disagreed with that items including "I let the other students do most of the work" (77.3\%); "My group members do not like me" (75.6\%); "My group members do not respect my opinions" (68.8\%); "I find it hard to express my thoughts when I work in a group' (62.1\%); and "My group members do not care about my feelings" (60.3\%). Table II shows the details of SAGE items the majority of students agreed or disagreed with.

TABLE II. LEARNING ATTITUDES

\begin{tabular}{|c|c|c|c|}
\hline SAGE Items & $\begin{array}{l}\text { Mean } \\
\text { (SD) }\end{array}$ & $\begin{array}{c}\text { Agree } \\
\text { Number } \\
(\%)\end{array}$ & $\begin{array}{c}\text { Disagree } \\
\text { Number } \\
(\%)\end{array}$ \\
\hline $\begin{array}{l}\text { When I work in a group, I want } \\
\text { to be with my friends. }\end{array}$ & $\begin{array}{c}4.21 \\
(0.851) \\
\end{array}$ & $274(83.8)$ & $10(3.0)$ \\
\hline $\begin{array}{l}\text { It is important to me that my } \\
\text { group gets the work done on } \\
\text { time. }\end{array}$ & $\begin{array}{c}4.09 \\
(0.792)\end{array}$ & $264(80.7)$ & $10(3.0)$ \\
\hline $\begin{array}{l}\text { I prefer to choose the students I } \\
\text { work with. }\end{array}$ & $\begin{array}{c}4.12 \\
(0.827) \\
\end{array}$ & 255 (78.0) & $8(2.4)$ \\
\hline $\begin{array}{l}\text { When I work in a group, I am } \\
\text { able to share my ideas. }\end{array}$ & $\begin{array}{c}3.83 \\
(0.707) \\
\end{array}$ & $247(75.5)$ & $13(4.0)$ \\
\hline $\begin{array}{l}\text { Everyone's ideas are needed if } \\
\text { we are going to be successful. }\end{array}$ & $\begin{array}{c}3.76 \\
(0.833) \\
\end{array}$ & $227(69.4)$ & $24(7.3)$ \\
\hline $\begin{array}{l}\text { I feel I am part of what is going } \\
\text { on in the group. }\end{array}$ & $\begin{array}{c}3.68 \\
(0.769) \\
\end{array}$ & $223(68.2)$ & $23(7.0)$ \\
\hline $\begin{array}{l}\text { When I work in a group, there } \\
\text { are opportunities to express } \\
\text { your opinions. }\end{array}$ & $\begin{array}{c}3.62 \\
(0.728)\end{array}$ & $215(65.8)$ & $25(7.6)$ \\
\hline $\begin{array}{l}\text { I learn to work with students } \\
\text { who are different from me. }\end{array}$ & $\begin{array}{c}3.63 \\
(0.799) \\
\end{array}$ & $212(64.9)$ & $27(8.2)$ \\
\hline $\begin{array}{l}\text { My group members help } \\
\text { explain things that I do not } \\
\text { understand. }\end{array}$ & $\begin{array}{c}3.62 \\
(0.867)\end{array}$ & $211(64.5)$ & 37 (11.3) \\
\hline
\end{tabular}




\begin{tabular}{|c|c|c|c|}
\hline $\begin{array}{l}\text { It is difficult to get together } \\
\text { outside of class. }\end{array}$ & $\begin{array}{c}3.67 \\
(1.022) \\
\end{array}$ & 208 (63.6) & $51(15.6)$ \\
\hline $\begin{array}{l}\text { I help my group members with } \\
\text { what I am good at. }\end{array}$ & $\begin{array}{c}3.64 \\
(0.695)\end{array}$ & $201(62.4)$ & 15 (4.6) \\
\hline $\begin{array}{l}\text { I become friends with my } \\
\text { group members. }\end{array}$ & $\begin{array}{c}3.57 \\
(0.869) \\
\end{array}$ & $195(59.6)$ & 37 (11.3) \\
\hline $\begin{array}{l}\text { I also learn when I teach the } \\
\text { material to my group members. }\end{array}$ & $\begin{array}{c}3.46 \\
(0.750) \\
\end{array}$ & $171(52.3)$ & $29(8.8)$ \\
\hline $\begin{array}{l}\text { When I work with other } \\
\text { students, I am able to work at } \\
\text { my own pace. }\end{array}$ & $\begin{array}{c}3.35 \\
(0.827)\end{array}$ & $165(50.4)$ & 48 (14.7) \\
\hline $\begin{array}{l}\text { Some group members forget to } \\
\text { do the work. }\end{array}$ & $\begin{array}{c}3.37 \\
(1.022)\end{array}$ & $164(50.1)$ & $72(22.1)$ \\
\hline $\begin{array}{l}\text { The work takes longer to } \\
\text { complete when I work with } \\
\text { other students. }\end{array}$ & $\begin{array}{c}3.42 \\
(1.030)\end{array}$ & $162(49.6)$ & $67(20.4)$ \\
\hline $\begin{array}{l}\text { I do not think a group grade is } \\
\text { fair. }\end{array}$ & $\begin{array}{c}3.24 \\
(1.102)\end{array}$ & $138(42.2)$ & $88(26.9)$ \\
\hline $\begin{array}{l}\text { I let the other students do most } \\
\text { of the work. }\end{array}$ & $\begin{array}{c}2.05 \\
(0.796)\end{array}$ & $17(4.2)$ & $253(77.3)$ \\
\hline $\begin{array}{l}\text { My group members do not like } \\
\text { me. }\end{array}$ & $\begin{array}{c}1.98 \\
(0.791)\end{array}$ & $9(2.8)$ & $247(75.6)$ \\
\hline $\begin{array}{l}\text { My group members do not } \\
\text { respect my opinions. }\end{array}$ & $\begin{array}{c}2.21 \\
(0.833)\end{array}$ & $22(6.7)$ & $225(68.8)$ \\
\hline $\begin{array}{l}\text { I find it hard to express my } \\
\text { thoughts when I work in a } \\
\text { group. }\end{array}$ & $\begin{array}{c}2.47 \\
(0.906)\end{array}$ & $54(16.5)$ & $203(62.1)$ \\
\hline $\begin{array}{l}\text { My group members do not care } \\
\text { about my feelings. }\end{array}$ & $\begin{array}{c}2.37 \\
(0.897)\end{array}$ & $32(9.7)$ & $197(60.3)$ \\
\hline
\end{tabular}

Among four learning attitudinal domains, the mean of quality of product and process was the highest (mean 46.22 and SD 8.03). The mean of student interdependence was 41.77 with SD 4.43. The mean of frustration with group members was 29.33, with SD 3.95. The mean of peer support was 21.97 with SD 3.85. Table III shows the analytical results of these four learning attitudinal domains.

\section{TABLE III. LEARNING ATTITUDINAL DOMAINS}

\begin{tabular}{|l|c|}
\hline Learning attitudinal domains & Mean (SD) \\
\hline Quality of product and process & $46.22(8.03)$ \\
\hline Student interdependence & $41.77(4.43)$ \\
\hline Frustration with group members & $29.33(3.95)$ \\
\hline Peer support & $21.97(3.85)$ \\
\hline
\end{tabular}

\section{C.}

\section{Relationships among learning attitudinal domains,} students' grades and /or other variables

Among four learning attitudinal domains, student interdependence was found to be the most significant domain positively correlations with grades $(\gamma=0.189, \mathrm{p}=0.001)$ and then followed by quality of product $(\gamma=0.119, \mathrm{p}=0.031)$. In addition, student interdependence was negatively correlated with the number of courses with group work $(\gamma=-0.105, \mathrm{p}=0.029)$. Table IV shows the correlations between learning attitudinal domains, students' grades and/or other variables.
TABLE IV. RELATIONSHIPS AMONG LEARNING ATTITUDINAL DOMAINS, STUDENTS' GRADES, AND OTHER VARIABLES

\begin{tabular}{|c|c|c|}
\hline & \multicolumn{2}{|c|}{ Students' grades } \\
\hline & Pearson's correlation & p-value \\
\hline Quality of product & 0.119 & 0.031 \\
\hline Student interdependence & 0.189 & 0.001 \\
\hline & Number of courses with group work \\
\hline & Pearson's correlation & p-value \\
\hline Student interdependence & -0.105 & 0.029 \\
\hline
\end{tabular}

\section{DISCUSSION}

Our study aimed at examining learning attitudes of undergraduate nursing students in collaborative learning approach. The results are important for nursing education since collaborating is favorable in nursing education - a professional training requiring much in multidisciplinary collaboration in order to ensure the delivery of optimal healthrelated quality of life to patients.

In general, our students were involved in four to five projects working in a group particularly in their first two years of study. It indicates that collaborative learning approach is applied in nursing education at a very initial stage. It is important to enable students to adapt to collaborative teamwork in order to enhance their ability and skills of collaboration. However, it is important to note that students' grades are positively correlated with quality of product and student interdependence. These two attitudinal domains indicate how the students are concerned about their academic success in learning to be determined through working in a group and the fairness of individual involvement and contribution during the process of collaborative learning. The result also showed that student interdependence was negatively correlated with number of courses with group work. Students who have fewer group projects may perceive better interdependence in collaborative development. It is an important note that numbers of group projects may affect the achievement in overall academic performance as their learning attitudes may not be fully devoted in collaborative learning.

The results identified three important components related to learning attitudes in collaborative learning, including preference of grouping, interpersonal relationship building and mutual learning, and barriers that include inadequate discussion and unfairness of grading.

\section{Preference of grouping}

The nursing students in this study prefer choosing their friends as their group members. It can be due to the fact that students would easily share their ideas and collaborate with their friends in order to complete the project on time. The study by Kouros and Abrambi (2006) has shown that students would rather work with others they had known already. In such group, students can particularly enjoy sharing their thoughts, experience and talents. It indicates that forming a group with friends may effectively facilitate collaboration and relationship building which is the key in collaborative learning. Collaborative learning requires members with 
heterogeneous capacities to work together so that it enhances positive student interdependence, promotes interpersonal relationships and fosters quality of group processing (Akhtar et al. 2012). Positive interdependence is an important component of achievement of learning goals while working with other group members (Akhtar et al. 2012).

\section{Interpersonal relationship building and mutual learning}

The study showed that the students reported to learn from sharing their ideas and helping others to learn. They also learn from the ideas of others with different backgrounds and talents. It is important to note that collaborative learning provides a platform for students to share their knowledge and abilities; students can learn from teaching and teach to learn from others through giving and receiving feedbacks (Butts, 2000; Hillyard et al., 2012; Johnsons and Johnson, 2009). Students learn more from different explanations, interpretations, and points of view on various subjects through working in a group rather than studying alone, especially when they are from various cultural backgrounds and individual experiences and capabilities (Laal and Ghodsi, 2012; Srinivas, 2015). This teaching-learning collaboration is a win-win situation that benefits the quality of learning and overall performance leading to better individual and group achievements. Likewise, previous studies have shown that students are committed to learning, making contributions and developing responsibility during collaborative learning (Laal and Ghodsi, 2012; Srinivas, 2015). In addition, students reported to be respected and cared in the process of collaborative learning. This mutual learning mechanism fosters interpersonal development and skills (Mehta and Kulshrestha, 2014; Srinivas, 2015).

\section{Barriers}

Collaborative learning approach can be more successful when the barriers are avoided. However, unresolved barriers may become conflicts that affect collaborative effectiveness and achievement. Students need to take longer time to complete their work. Two important barriers, including inadequate discussion and unfairness of grading, are identified in this study.

Inadequate discussion: Inadequate discussion reduces interaction and understanding among team members, resulting in misunderstanding and conflicts (Chan and Chen, 2010; Jehn and Mannix, 2001). Discussion is important for students to understand their part of involvement and individual tasks to complete the job on time. Collaborative learning emphasizes exchange individual opinions, engagement of in in-depth discussions and more responsible for own learning sharing of workload and mutual monitoring (Anderson, 2013; Chiriac, 2014; Gaudet et al., 2010; Tyler, 2014). Students are able to share their points of view and work on a topic within their scopes of interests through discussions with other group members (Ames and Archer, 1988; Hillyard et al., 2012; Kouros and Abrami, 2006). When a group member is struggling and unable to go forward, discussion helps reorganization and redistribution work based on group agreement and empowerment. Therefore, discussion enables students to solve their difficulties together and also seek assistance from their supervisor timely. In that sense, educators need to set adequate classroom discussion schedule while designing timetable and help students develop objectives for each discussion. Students should be required to reflect what they have learned regularly and additional discussion may be necessary when objectives are not achieved. Educators need to give timely advice to direct group discussion effectively.

Unfairness of grading: In our study, students were concerned about the fairness of grading. Students would show their success in collaborative learning by attaining higher grades for their academic performance. However, collaborative learning cannot guarantee equal distribution of job assignments, and work overload for certain members is always an issue. It is better to distribute the workload according to individual ability of group members. Such distribution benefits the progress and quality of work. Student involvement is crucial to succeed in collaborative learning (Hillyard et al., 2012; Laal and Ghodsi, 2012). Therefore, students should have clearly understood their responsibilities in order to achieve a better learning from both person and group. In addition, students should learn that learning ability is various from individual to individual. Collaborative learning will be more effective when the pace of learning among students may move forward altogether. Educators must pay more attention to the progress of individual assignment. Conflicts occur when group dynamics is violated leading to ineffective collaborative learning that negatively influences individual and group performance and grading. In other words, educators need to pay more attention to the fairness of job distribution and the grading according to students' individual participation and to avoid free riders who reduce group dynamics and increase workload of group members. A job allocation list may help students focus on their task individually. Educators may closely monitor individual performance according to the list. Regular group evaluation can be adopted to understand better how well individuals are functioning in their respective groups and to ensure fair distribution of work in a group project. Evaluation provides appropriate feedback and identifies possible barriers affecting students' learning, such as uneven job allocation and overly high expectation in a group (Chan and Chen, 2010).

Because the cross-sectional design was used in this study, the findings could not detect changes of attitudes and performance in collaborative learning approach over a period of time. A longitudinal study can be used in future study.

\section{CONCLUSION}

Collaborative learning approach is an effective teaching mode to enhance knowledge and skills. This study demonstrated the components and barriers of learning achievement through collaborative learning approach. Preference of grouping and interpersonal relationship building and mutual learning are the significant components for successful collaborative learning. The barriers include inadequate discussion and unfairness of grading that induce 
conflicts. The study results hold implicit and specific advice for educators and curriculum developers to design effective collaborative learning in order to achieve better students' learning outcomes through promoting benefits and avoiding barriers of collaborative learning.

\section{ACKNOWLEDGMENT}

I would like to express my deepest appreciation to the Centre for the Study of Learning and Performance (CSLP) for the use of SAGE in this study and to the School Research Grant from School of Nursing at Tung Wah College.

\section{REFERENCES}

[1] Akhtar, K., Perveen, Q., Kiran, S., Rashid, M., \& Satti, A. K. (2012). A study of student's attitudes towards cooperative learning. International Journal of Humanities and Social Sciences, 2(11), 141-147.

[2] Ames, C. \& Archer, J. (1988). Achievement goals in the classroom: students' learning strategies and motivation processes. Journal of Educational Psychology, 80(3), 260267.

[3] Anderson, M. (2013). Advantages and disadvantages of cooperative education for high school students. Globalpost: America's world news site, Demand Media. Available http://everydaylife.globalpost.com/advantagesdisadvantages-cooperative-education-high-schoolstudents-12404.html.

[4] Austria, M.J., Baraki, K., \& Doig, A.K. (2013). Collaborative Learning Using Nursing Student Dyads in the Clinical Setting. International Journal of Nursing Educational Scholarship, 10(1), 1-8.

[5] Butts, E.A. (2000). Overcoming student resistance to group work. Teaching English in the Two-Year College, 28(1): 80-83.

[6] Chan, L.H. \& Chen, C.H. (2010). Conflict from teamwork in project-based collaborative learning. International Society for Performance Improvement, 49(2): 23-27.

[7] Chiriac, E.H. (2014). Group work as an incentive for learning-students' experiences of group work. Frontiers in Psychology, 5. doi: 10.3389/fpsyg.2014.00558

[8] Copp, S. L. (2002). Using cooperative learning strategies to teach implications of the nurse practice act. Nurse Educator, 27(5), 236-241.

[9] D'Souza, M. S., Venkatesaperumal, R., Radhakrishnan, J., \& Balachandran, S. (2013). Engagement in clinical learning environment among nursing students: Role of nurse educators. Open Journal of Nursing, 3, 25-32.

[10] Esmat, N., Abas, A., Sadat, S.B.M., 2013. University engagement and collaborative learning in nursing students of Kerman University of Medical Sciences. Iranian Journal of Nursing and Midwifery Research, 18(6), 505510.

[11] Gaudet, A.D., Ramer, L.M., Nakonechny, J., Cragg, J.J., \& Ramer, M.S. (2010). Small-group learning in an upperlevel university biology class enhances academic performance and student attitude toward group work. PLOs ONE 5 (12), doi: 10.1371/journal.pone.0015821. http://www.plosone.org/article/info\%3Adoi\%2F10.1371\% 2Fjournal.pone.0015821.

[12] Hillyard, C., Gillespie, D., Littig, P. (2012). University students' attitudes about learning in small groups after frequent participation. Active Learning in Higher Education, 11(1), 9-20.
[13] Houldsworth, C. \& Mathews, B.P. (2000). Group composition, performance and educational attainment. Education and Training, 42(1), 40-53.

[14] Ismail, I., Idrus, R. M., Baharum, H., Rosli, M., \& Ziden, A.A. (2011). The Learners' attitudes towards using different learning methods in E-learning portal environment. International Journal of Emerging Technologies in Learning, 6(3), 49-52.

[15] Jehn, K. \& Mannix, E. (2001). The dynamic nature of conflict: A longitudinal study of intragroup conflict and group performance. Academy of Management Journal, 44(2), 238-251.

[16] Johnson, D.W. \& Johnson, R.T. (2009). An educational psychology success story: social interdependence theory and cooperative learning. Educational Researcher, 38(5), 365-379.

[17] Kanthan, R. \& Mills, S. (2007). Cooperative learning in the first year of undergraduate medical education. World Journal of Surgical Oncology, doi: 10.1186/1477-7819-5136.

[18] Kokemuller, N. (2007). Advantages and Disadvantages of cooperative learning group grades. Globalpost: America's world news site, Demand Media. Retrieved from http://everydaylife.globalpost.com/advantagesdisadvantages-cooperative-learning-group-grades4979.html

[19] Kouros, C. \& Abrami, P.C. (2006). How do students really feel about working in small groups? The role of student attitudes and behaviours in cooperative classroom settings. Attitudes toward Small Group Learning, Centre for the Study of Learning and Performance. Concordia University, Montreal, Canada

[20] Laal, M. \& Ghodsi, S.M. (2012). Benefits of collaborative learning. Procedia-Social and Behavioral Sciences, 31, 486-490.

[21] Laal, M., Laal, M., \& Khattami-Kermanshahi, Zh. (2012). 21 st century learning: learning in collaboration. ProcediaSocial and Behavioral Sciences, 47, 1696-1701.

[22] Mabrouk, P. A (2007) Active learning: Models from the analytical sciences. ACS Symposium Series 970. Washington, DC: American Chemical Society.

[23] McCrorie, P. (2006). Teaching and Leading Small Groups. Association for the Study of Medical Education, Edinburgh.

[24] Mehta, S. \& Kulshrestha, A.K. (2014). Implementation of cooperative learning in science: A developmental-cumexperimental study. Hindawi Publishing Corporation Education Research International article ID: 431542, http://dx.doi.org/10.1155/2014/431542.

[25] Mueller-Joseph, L.J. \& Nappo-Dattoma, L. (2013). Collaborative learning in pre-clinical dental hygiene education. International Journal of Dental Hygiene, 87(2), 64-72.

[26] Noohi, E., Abazadeh, A., Maddah, S.s.B. (2013. University engagement and collaborative learning in nursing students of Kerman University of Medical Sciences. Iranian Journal of Nursing and Midwifery Research, 18(6), 505-510.

[27] Srinivas, H. (2015). Collaborative learning: 44 benefits of collaborative learning. Retrieved from http://www.gdrc.org/kmgmt/c-learn/44html

[28] Tyler, M. (2014). Advantages and disadvantages of student group works. Retrieved from http://www.ehow.com/info_12018381_advantagesdisadvantages-student-group-projects. $\overline{h t m l}$

[29] Van Offenbeek, M. (2001). Processes and outcomes of team learning. European Journal of Work \& Organizational Psychology, 10(3), 303-317. 